\title{
Effect of Non-alcoholic Fatty Liver Disease on Some of Bone Biomarkers in Men
}

\author{
Dalal Al-Akabi ${ }^{1 *}$ (D), Faris S. Kata ${ }^{2}$ \\ ${ }^{1}$ Department of Medical Laboratory Techniques, Al-Kunooze University College, Basrah, Iraq; ${ }^{2}$ Department of Biology, College \\ of Education For Pure Sciences, University of Basrah, Basrah, Iraq
}

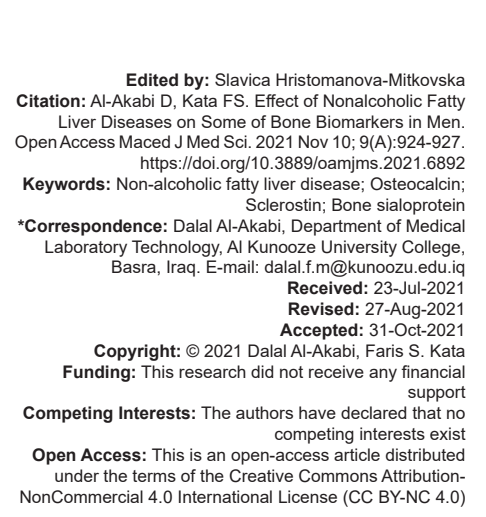

Abstract

BACKGROUND: Non-alcoholic fatty liver disease (NAFLD) is one of the common liver diseases worldwide that is not associated with alcohol consumption; it is a group of disorders caused by fat accumulation in the liver.

AIM: The research aims to assess the levels of serum sialoprotein, sclerostin, and osteocalcin in men with NAFLD.

METHODS: The current study was conducted in Basra city, Iraq in 2020, which includes 400 men with NAFLD, age ranges between ( 30 and 50 ) years, and 400 matched health men as controls, serum levels of study parameters were measured using the ELISA method.

RESULTS: The results showed a significant decrease in the levels of serum osteocalcin but a non-significant difference in sclerostin and bone sialoprotein in men with NAFLD comparing with the control group, also age and disease severity factors did not show any significant effect on study parameters in the patient's group.

CONCLUSION: In conclusion, men with NAFLD may be prone to some disturbances in the bone health regardless of disease progression and age in Basrah city.

\section{Introduction}

Non-alcoholic fatty liver disease (NAFLD) is considered one of the world's most prevalent liver disorders, and several factors contribute to the pathogenesis of the disease, such as environmental and genetic factors [1]. It includes various degrees of disorders such as accumulation of fat in the liver or the development of inflammations as well as the occurrence of a distinct dysfunction in the liver cells [2]. NAFLD also encompasses other tissue disorders from steatosis and non-alcoholic steatohepatitis (NASH) to cirrhosis, and some patients also experience liver cancer [3]. The prevalence of NAFLD is associated with increased obesity rates in societies, and it is a common disease that is difficult to detect early because it lacks clear symptoms at the beginning of its appearance, but it can be detected in a laboratory through an increase in liver enzymes also NAFLD is associated with other diseases such as heart disease, diabetes and thyroid disease [4]. Osteoporosis entails reducing bone mass and changes in bone structure resulting in increased bone breakability and increased risk of rupture, the causes of osteoporosis include increased age, low body mass index, low bone mineral density, Vitamin D and calcium, smoking, alcohol, and other factors, including biomarker measures of bone turnover, may be useful for testing osteoporosis therapies but not for diagnosis [5]. The liver produces many proteins that play an important role in bone metabolism and the organization of its different pathways, but so far the pathogenesis of this is not sufficiently clear, as the relationship between NAFLD and the apparent decrease in body bone mineral density levels has been addressed recently [6]. Several studies found NAFLD to be a risk factor associated with low bone mineral levels and its role in hepatitis and osteoporosis stimulation [7], [8]. Chronic inflammatory processes mediate the relationship between bone disorders in people with NAFLD and liver virus infections, liver centralizes the relationship between muscle, adipose, and muscle tissue, as well as many molecules produced from osteoblast mediators that link the liver to these tissues, NAFLD is one of the most common liver diseases related to metabolic disorders and insulin resistance and the worsening of these patients' bone homeostasis has recently been addressed in light of the effect of age and gender, among pathophysiological features that link NAFLD and weak bones is a deficiency of the Vitamin D, chronic inflammation, and GH/IGF-1 axis turbulences [9], [10]. The clinical role of bone markers in the diagnosis and management of osteoporosis in chronic liver disease is still uncertain, but they may be useful for checking bone loss or evaluating the patients' response to treatments [11].

The study assesses the effect of NAFLD on some of the men's bone biomarkers and shows the 
effect of age and disease severity on these criteria to clarify the relationship between NAFLD and general bone weakness.

\section{Methods}

The current research was included 800 samples include 400 people with NAFLD (180 with clear nonalcoholic steatosis, 100 with steatohepatitis, and 120 with cirrhosis), age ranged from 30 to 50 years of age and 400-matched health people as controls with NAFLD were confirmed by ultrasound and laboratory diagnosis under the supervision of a specialized internal medicine doctor. Serum levels of bone sialoprotein, sclerostin, and osteocalcin were measured using the ELISA (Elabscience Kits/USA) method. For all patients in the study, the exclusion criteria include alcohol, smoking, prolonged medication use, other liver diseases, renal disease, diabetes mellitus, hypertension, immune, and hormonal diseases. The statistical analysis is carried out using SPSS version 23, whereby $p<0.05$ is considered statistically significant, and data are expressed as (mean $\pm \mathrm{SD}$ ) and the difference in the levels of these markers between NAFLD cases and control was evaluated by t-test, one-way ANOVA test and Post hoc tests.

\section{Results}

Table 1 showed a significant decrease in the levels of serum osteocalcin but sclerostin and bone sialoprotein did not show any significant difference in NAFLD patients compared with a control group.

Table 1: Comparison of serum parameters between NAFLD patients and control groups

\begin{tabular}{lll}
\hline Serum parameters & NAFLD $(\mathrm{n}=400)$ & Control $(\mathrm{n}=400)$ \\
\cline { 2 - 3 } & Mean $\pm \mathrm{SD}$ & \\
\hline Osteocalcin $(\mathrm{ng} / \mathrm{mL})$ & $3.62 \pm 6.67$ & $15.43 \pm 13.25^{*}$ \\
Sclerostin $(\mathrm{gg} / \mathrm{mL})$ & $495.55 \pm 428.41$ & $447.38 \pm 330.78$ \\
Bone sialoprotein $(\mathrm{ng} / \mathrm{mL})$ & $13.50 \pm 9.15$ & $14.23 \pm 8.79$ \\
\hline${ }^{*}$ Significant decrease at the $(\mathrm{p} \leq 0.05)$. NAFLD: Non-alcoholic fatty liver disease. &
\end{tabular}

The study results showed that there is a significant decrease in serum osteocalcin and sclerostin in patients with NAFLD compared to controls in both age groups, except bone sialoprotein did not show a significant difference, and the comparison among age categories of NAFLD patients showed a non-significant difference in all study parameters, Table 2.

As in Table 3 serum osteocalcin, sclerostin and bone sialoprotein levels did not show any significant difference in NAFLD patients when compared with control for disease severity categories, also the comparison between disease severity categories of NAFLD patients did not show a significant difference.
Table 2: Comparison of serum parameters between NAFLD patients and control groups according to age categories

\begin{tabular}{lll}
\hline Serum parameters & NAFLD $(\mathrm{n}=400)$ & Control $(\mathrm{n}=400)$ \\
\cline { 2 - 3 } & Mean \pm SD & \\
\hline Age & $(30-40)$ year $(\mathrm{n}=220)$ & $(30-40)$ year $(\mathrm{n}=180)$ \\
Osteocalcin $(\mathrm{ng} / \mathrm{mL})$ & $2.75 \pm 5.53^{\mathrm{a}}$ & $13.95 \pm 11.05^{\star}$ \\
Sclerostin $(\mathrm{pg} / \mathrm{mL})$ & $371.93 \pm 324.95^{\mathrm{a}}$ & $482.81 \pm 346.36$ \\
Bone sialoprotein $(\mathrm{ng} / \mathrm{mL})$ & $13.13 \pm 7.60^{\mathrm{a}}$ & $13.49 \pm 9.55$ \\
Age & $(41-50)$ year $(\mathrm{n}=180)$ & $(41-50)$ year $(\mathrm{n}=220)$ \\
Osteocalcin $(\mathrm{ng} / \mathrm{mL})$ & $4.69 \pm 7.88^{\mathrm{b}}$ & $16.69 \pm 15.04^{*}$ \\
Sclerostin $(\mathrm{pg} / \mathrm{mL})$ & $646.64 \pm 496.65^{\mathrm{b}}$ & $418.41 \pm 322.69$ \\
Bone sialoprotein $(\mathrm{ng} / \mathrm{mL})$ & $13.95 \pm 10.97^{\mathrm{b}}$ & $14.85 \pm 8.30$ \\
\hline "Significant decrease at the $(\mathrm{p} \leq 0.05)$. Different letters indicate that there is non-significant difference \\
between the two age groups of NAFLD patients for each parameter. NAFLD: Non-alcoholic fatty liver \\
disease.
\end{tabular}

\section{Discussion}

The current study showed that the levels of osteocalcin in NAFLD patients decrease compared to the healthy group of men. Osteocalcin is a hormone (non-collagenic protein) contained in abundant quantities in the bones, acts as a mediator between the skeleton system and adipose tissue, its low levels in adults result in a marked weakening in the bone structure, and low levels of this hormone have also been reported in the liver fibrosis and are an important factor in the progress of NAFLD [12], [13], [14].

Table 3: Comparison of serum parameters between NAFLD patients according to disease severity

\begin{tabular}{llll}
\hline Disease severity & NAFLD $(\mathrm{n}=400)$ & & \\
\cline { 2 - 4 } Serum parameters & $\begin{array}{l}\text { Steatosis } \\
(\mathrm{n}=180)\end{array}$ & $\begin{array}{l}\text { Steatohepatitis } \\
(\mathrm{n}=100)\end{array}$ & $\begin{array}{l}\text { Cirrhosis } \\
(\mathrm{n}=120)\end{array}$ \\
\cline { 2 - 4 } & Mean $\pm \mathrm{SD}$ & & \\
\hline Osteocalcin $(\mathrm{ng} / \mathrm{mL})$ & $3.82 \pm 6.57$ & $2.45 \pm 3.72$ & $4.28 \pm 8.84$ \\
Sclerostin $(\mathrm{pg} / \mathrm{mL})$ & $471.16 \pm 510.32$ & $539.16 \pm 358.91$ & $495.80 \pm 374.35$ \\
Bone sialoprotein $(\mathrm{ng} / \mathrm{mL})$ & $12.73 \pm 9.37$ & $11.29 \pm 7.65$ & $16.49 \pm 9.91$ \\
\hline NAFLD: Non-alcoholic fatty liver disease. & &
\end{tabular}

Osteocalcin improves NAFLD's progression by stimulating the Nrf2 pathway to cause oxidative stress and inhibits the JUK pathway, where low levels of osteocalcin are observed in children with NAFLD and who suffer from obesity, this decrease also increases with disease severity, osteocalcin plays a key role in the metabolism of fats and glucose, thus contributing to promoting disease progression [15]. Low levels of osteocalcin in children and adolescents with NAFLD are a vital sign of disease severity for this age group [16]. Osteocalcin regulates bone metabolism and is a diagnostic criterion for bone formation in the body, the previous studies indicated the relationship of NAFLD with the percentage of minerals in bones where there is an inverse relationship between them in men, in particular the density of minerals present in the hips [17]. Osteocalcin may play a role in the development of insulin resistance associated with fatty liver disease [18]. Serum osteocalcin levels are not directly correlated with NAFLD but recorded a low level of osteocalcin in NAFLD men than in control, the occurrence of NAFLD increased gradually with decreasing levels of osteocalcin, and independently related to ALT in these men [19]. Osteocalcin regulates metabolism in the 
form (undercarboxylated/uncarboxylated), where an inverse association was observed between NAFLD and osteocalcin due to it reduces liver lipogenesis by reducing expression of SREBP-1c [20]. Osteocalcin is a hormone derived from bone, plays an important role in the relationship between energy and bone metabolism, it was found that treating mice with NAFLD relieved the severity of the disease through the GPRC6A signaling pathway and that GPRC6A in the liver could be used as a target for NAFLD treatment [21]. The present study showed a non-significant variance in serum sclerostin levels in NAFLD patients when compared with the healthy men group. Sclerostin is a glycoprotein produced by bone cells and known to inhibit Wnt signaling [22]. Sclerostin is a major regulator of osteocytes produced from osteocytes and impedes the process of differentiation and proliferation of the osteoblasts, as result, osteogenesis is impaired by antagonizing wnt signaling through association with (LRP) 5/6 transmembrane receptors [23]. Decreased serum sclerostin levels were recorded in NASH patients this low level is also observed in patients with osteoporosis, which is noted in the advanced stages of liver diseases, osteoporosis results from weak bone formation, where sclerostin regulates the Wnt signaling pathway that is important in regulating of bone formation [24], [25]. In advanced cirrhosis, the sclerostin levels recorded as much as more than in those patients with early stages of disease [26]. The bone formation may be affected by the liver disease due to the toxic substances and sclerostin that lead to osteoporosis in patients with advanced stages of liver cirrhosis [9]. The severity of NAFLD is closely related to the intensity of the bone minerals and with osteocalcin, sclerostin levels play an important role in bone formation [27]. The present results showed that serum bone sialoprotein levels non-significant difference in NAFLD patients compared with the healthy men group so this finding is in agreement with another study that showed no difference was observed in the level of bone sialoprotein in cirrhosis patients with various degrees of the disease [28]. Bone sialoprotein is a phosphorylated protein located outside the cells, it was found to be linked with the addition of minerals to different tissues such as periodontium as well as its role in the formation of long bones [29]. Bone sialoprotein is one of the liver stellate cell-activating signaling molecules, associated with liver fibrosis and cell injury, its concentration in plasma was prognostic of liver fibrosis and it is not only involved in the cirrhosis development but also the pathogenesis of other liver diseases like steatohepatitis, the non-alcoholic [30]. It was suggested that NAFLD is associated with osteoporotic fractures in middle-aged and elderly men but not with the low mineral density of the bones, Osteoporosis affects bone metabolism, as the patient suffers from a lack of bone minerals, which makes them fragile and prone to breakage easily, also, the level of bone sialoprotein production from osteoblasts decreases, so it was found that transplanting osteoblasts into rats with osteoporosis restores homeostasis of the bone remodeling [31], [32].

\section{Conclusion}

Men in Basrah, who suffer from NAFLD, are at risk of emerging bone abnormalities and it does not associate with the disease severity and age factors. Serum osteocalcin could be an indicator for bone abnormalities. Sclerostin and bone sialoprotein did not implicate in NAFLD patients. The severity of NAFLD is not influenced by changing levels of bone markers of serum osteocalcin, sclerostin, and bone sialoprotein. Further investigation on female gender to show the association may be a benefit.

\section{Authors' Contribution}

Study design: DFA and FSK. Main manuscript preparation: DFA. An important revision of the manuscript: DFA and FSK. All authors read and approved the final manuscript.

\section{References}

1. Arab JP, Arrese M, Trauner M. Recent insights into the pathogenesis of nonalcoholic fatty liver disease. Ann Rev Pathol. 2018;13:321-50. https://doi.org/10.1146/ annurev-pathol-020117-043617|

PMid:29414249

2. Haas JT, Francque S, Staels B. Pathophysiology and mechanisms of nonalcoholic fatty liver disease. Ann Rev Physiol. 2016;78:181-205. https://doi.org/10.1146/ annurev-physiol-021115-105331 PMid:26667070

3. Calzadilla BL, Adams LA. The natural course of non-alcoholic fatty liver disease. Int J Mol Sci. 2016;17(5):774. https://doi. org/10.3390/ijms17050774 PMid:27213358

4. Akkawi I, Zmerly H. Osteoporosis: Current concepts. Joints. 2018;6(2):122-7. https://doi.org/10.1055/s-0038-1660790 PMid:30051110

5. Kumar P, Saini M, Kumar D, Bharadwaj A, Yadav PS. Estimation of endogenous levels of osteopontin, total antioxidant capacity and malondialdehyde in seminal plasma: Application for fertility assessment in buffalo (Bubalus bubalis) bulls. Reprod Domest Anim. 2017;52(2):221-6 https://doi.org/10.1111/rda.12882 PMid:27862407

6. Eshraghian A. Bone metabolism in non-alcoholic fatty liver disease: Vitamin D status and bone mineral density. Miner Endocrinol. 2017;42(2):164-72. https://doi.org/10.23736/ 
s0391-1977.16.02587-6

PMid:27973461

7. Shateri K, Vousoghian S, Oshnoei S, Mohammadi A. Association of osteoporosis with non-alcoholic fatty liver disease in adults. J Adv Pharm Educ Res. 2019;9(2):408.

8. Shen Z, Cen L, Chen X, Pan J, Li Y, Chen W, et al. Increased risk of low bone mineral density in patients with non-alcoholic fatty liver disease: A cohort study. Eur J Endocrinol. 2020;182(2):15764. https://doi.org/10.1530/eje-19-0699

PMid:31770104

9. Danford CJ, Trivedi HD, Bonder A. Bone health in patients with liver diseases. J Clin Densitom. 2020;23(2):212-22. https://doi. org/10.1016/j.jocd.2019.01.004

PMid:30744928

10. Filip R, Radzki RP, Bieńko M. Novel insights into the relationship between nonalcoholic fatty liver disease and osteoporosis. Clin Interv Aging. 2018;13:1879-91. https://doi.org/10.2147/cia. s170533

PMid:30323574

11. Stein EM, Cohen A, Freeby M. Severe Vitamin D deficiency among heart and liver transplant recipients. Clin Transplant. 2009;23(6):861-5. https://doi. org/10.1111/j.1399-0012.2009.00989.x

PMid:19453643

12. Berezovska O, Yildirim G, Budell WC. Osteocalcin affects bone mineral and mechanical properties in female mice. Bone. 2019;128:115031. https://doi.org/10.1016/j.bone.2019.08.004 PMid:31401301

13. Aller R, Castrillon JL, de Luis DA. Relation of osteocalcin with insulin resistance and histopathological changes of nonalcoholic fatty liver disease. Ann Hepatol. 2016;10(1):50-5. https://doi. org/10.1016/s1665-2681(19)31587-x PMid:21301010

14. Hu X, Hua $Y$, Shi Z. Association of serum 25-hydroxy Vitamin D and osteocalcin levels with non-alcoholic fatty liver disease. Int J Clin Exp Med. 2016;9(11):22750-7.

15. Du J, Zhang M, Lu J. Osteocalcin improves nonalcoholic fatty liver disease in mice through activation of Nrf2 and inhibition of JNK. Endocrine. 2016;53(3):701-9. https://doi.org/10.1007/ s12020-016-0926-5

PMid:26994931

16. Ebrahim HT, El-Behery EG. Osteocalcin: A new biomarker for nonalcoholic fatty liver disease (NAFLD) in children and adolescents. Clin Med Biochem. 2017;3:2471-663. https://doi. org/10.4172/2471-2663.1000133

17. Yang HJ, Shim SG, Ma BO, Kwak JY. Association of nonalcoholic fatty liver disease with bone mineral density and serum osteocalcin levels in Korean men. J Gastroenterol Hepatol. 2016;28(3):338-44. https://doi.org/10.1097/ meg. 0000000000000535

PMid:26636404

18. Fernández-Real JM, Ortega F, Gómez-Ambrosi J, Salvador J, Frühbeck G, Ricart W. Circulating osteocalcin concentrations are associated with parameters of liver fat infiltration and increase in parallel to decreased liver enzymes after weight loss. Osteoporos Int. 2010;21(12):2101-7. https://doi.org/10.1007/ s00198-010-1174-9

PMid:20204603

19. Dou J, Ma X, Fang Q. Relationship between serum osteocalcin levels and non-alcoholic fatty liver disease in Chinese men. Clin Exp Pharmacol Physiol. 2013;40(4):282-8. https://doi. org/10.1111/1440-1681.12063

PMid:23369196

20. Xia M, Rong S, Zhu X, Yan H, Chang X, Sun X, et al Osteocalcin and non-alcoholic fatty liver disease: Lessons from two population-based cohorts and animal models. J Bone Miner Res. 2021;36(4):712-28.' https://doi.org/10.1002/jbmr.4227 PMid:33270924

21. Zhang $M$, Nie $X$, Yuan $Y$, Wang $Y, M a X$, Yin J, et al. Osteocalcin alleviates nonalcoholic fatty liver disease in mice through GPRC6A. Int J Endocrinol. 2021;2021:9178616. https://doi. org/10.1155/2021/9178616

PMid:33531899

22. Mantovani A, Sani E, Fassio A. Association between nonalcoholic fatty liver disease and bone turnover biomarkers in post-menopausal women with Type 2 diabetes. Diabetes Metab. 2019;45(4):347-55. https://doi.org/10.1016/j.diabet.2018.10.001 PMid:30315891

23. Neong SF, Billington EO, Congly SE. Sexual dysfunction and sex hormone abnormalities in patients with cirrhosis: Review of pathogenesis and management. Hepatology. 2018;69(6):268395. https://doi.org/10.1002/hep.30359

24. Polyzos SA, Anastasilakis AD, Kountouras J. Circulating sclerostin and dickkopf-1 levels in patients with nonalcoholic fatty liver disease. J Bone Miner Metab. 2016;34(4):447-56. https://doi.org/10.1007/s00774-015-0687-x

PMid:26056025

25. Guañabens N, Parés A. Osteoporosis in chronic liver disease. Liver Int. 2018;38(5):776-85. https://doi.org/10.1111/liv.13730 PMid:29479832

26. Yang YJ, Kim DJ. An overview of the molecular mechanisms contributing to musculoskeletal disorders in chronic liver disease: Osteoporosis, sarcopenia, and osteoporotic Sarcopenia. Int J Mol Sci. 2021;22(5):2604.| https://doi.org/10.3390/ijms22052604 PMid:33807573

27. Mantovani A, Gatti D, Zoppini G. Association between nonalcoholic fatty liver disease and reduced bone mineral density in children: A meta-analysis. Hepatology. 2019;70(3):812-23. https://doi.org/10.1002/hep.30538

PMid:30706504

28. Harvey B. The Characterization of the Rat Bone Sialoprotein Knockout Phenotype. Canada: Western University; 2019.]

29. Benz F, Bogen A, Praktiknjo M. Serum levels of bone sialoprotein correlate with portal pressure in patients with liver cirrhosis. PLoS One. 2020;15(4):e0231701. https://doi.org/10.1371/ journal.pone.0231701 PMid:32302330

30. Bruha R, Vitek L, Smid V. Osteopontin-a potential biomarker of advanced liver disease. Ann Hepatol. 2020;19(4):344-52. https://doi.org/10.1016/j.aohep.2020.01.001 PMid:32005637

31. Mantovani A, Dauriz M, Gatti D. Systematic review with metaanalysis: Non-alcoholic fatty liver disease is associated with a history of osteoporotic fractures but not with low bone mineral density. Aliment Pharmacol Ther. 2019;49(4):375-88. https://doi. org/10.1111/apt.15087

PMid:30600540

32. Mahmoud NS, Mohamed MR, Ali MA. Osteoblast-based therapy-a new approach for bone repair in osteoporosis: Preclinical setting. Tissue Eng Regen Med. 2020;17(3):363-73. https://doi.org/10.1007/s13770-020-00249-5

PMid:32347454 